\title{
School enrollment in Slovakia
}

\author{
Margita Janotová* \\ Catholic University Address of Institution, Hrabovská cesta 1, Ruzomberok, Slovakia \\ *E-mail address: margitajanotova@gmail.com
}

\begin{abstract}
In this paper the author analyzes the development of unemployed graduates in Slovakia. The aim of this paper is to analyze the course of unemployment of graduates, the main causes of unemployment and ways to address the situation in the labor market.
\end{abstract}

Keywords: labor market; unemployment; young people aged 15-24; graduates

\section{INTRODUCTION}

Dramatic rise in youth unemployment due to the global financial and economic crisis is one of the key challenges of the current labor market. Unemployment manifests itself as one of the most serious economic problems, which impacts on almost every aspect of the unemployed individual as well as his loved ones. The most vulnerable groups in the labor market tend to be young people who are seeking their first job after they have completed their education. The paper attempts to show the development of graduate's unemployment rate, from high school to university graduates. The author analyses those fields of study in which the graduate's unemployment is the most notable. The more promising courses and places where the graduate's unemployment rate is significantly influenced by regional disparities are presented in the paper together with suggested measures to improve matters.

\section{CURRENT SYSTEM OF EDUCATION AND LABOUR MARKET}

Slovakia has been suffering poor linkage of education to the labor market, which results in high unemployment of graduates. It is not just the lack of jobs in the labor market for this group, but often the opposite is true when there are enough jobs, but the lack of qualified graduates. Two thirds of graduates end humanities oriented disciplines (economics, law and social work) while the labor market lacks mainly the graduates of Technical Education (programmers, electricians), who are in short supply as a result of inadequate communication between the system of education, the labor market and employers.

Slovakia needs the reform of the system of education so that the graduates get applicable in the labor market.

Graduates are disadvantaged by the fact that they have no work experience and experience in their field of study. Some put a lot of energy into the studies but there is no demand on the labor market. For those unemployed not only economic but also psychological 
problems increase the risk of anti-social behavior and creating unhealthy dependence on parents.

In my work I use data on unemployment, which are collected by the Central Office of Labour, Social Affairs and Family and data on graduates of schools of the Institute of Information and Prognoses of Education.

By definition defined by the Law No.5 / 2004 on Employment Services a school graduate is a citizen under 25 years of age, who ended systematic vocational preparation in full-time study less than two years agoand has not earned his first regular pay.

\subsection{Graduate's unemployment rate}

The unemployment rate in Slovakia is assessed in two ways, according to the Statistical Office of the Slovak Republic based on labor force survey and by the Office of Labour, Social Affairs and Family of the available number of job seekers in the total number of applicants. Each of these sources is characterizes unemployment in Slovakia from a different perspective. One based on the official unemployment register, which is supported by national legislation, the other one is survey based on standard international methodology. Due to the diversity of methodologies, the data can not completely coincide.

The following table analyzes the development of the overall rate for the period.

Table 1. Unemployment rate in Slovakia (\%).

\begin{tabular}{|c|c|c|c|c|c|c|c|c|c|c|}
\hline $\begin{array}{c}\text { unemployment } \\
\text { rate }\end{array}$ & 2003 & 2004 & 2005 & 2006 & 2007 & 2008 & 2009 & 2010 & 2011 & 2012 \\
\hline total & 17,4 & 18,1 & 16,2 & 13,3 & 11,0 & 9,6 & 12,1 & 14,4 & 13,5 & 14,0 \\
\hline graduates & 6,8 & 6,3 & 6,1 & 6,0 & 6,5 & 7,5 & 10,2 & 9,0 & 9,2 & 9,3 \\
\hline $\begin{array}{c}\text { universities } \\
\text { Graduates }\end{array}$ & 0,1 & 0,8 & 0,6 & 0,7 & 0,9 & 0,8 & 1,4 & 1,2 & 1,4 & 2,1 \\
\hline
\end{tabular}

Sources of data: Basic statistical indicators of the labor market; monthly statistics ÚPSVR, own calculations; http: // www.upsvar.sk

Unemployment rate was relatively stable during the years 2003 to 2008, the rate of graduate's unemployment significantly increased in 2009 when it reached $10.2 \%$. Unfavorable situation with a high number of unemployed graduates continued in 2010, the unemployment rate was $9 \%$ and the number amounted to 35246 unemployed job seekers. In 2011 the rate peaked at number 34025 candidates. In 2012 the number of unemployed university graduates increased significantly to $2.1 \%$, representing 5,193 unemployed graduates.

\subsection{Unemployment graduates by fields of study}

Table. 2 documents the number of unemployed graduates (secondary and tertiary). The lowest numbers of unemployed graduates were in 2007 and 2008. The declining trend was associated with young people moving abroad for work, but also with made structural changes, implementation of reforms and action of tools of active labor market policy of the state. 
Table 2. Number of unemployed graduates by fields of study.

\begin{tabular}{|c|c|c|c|c|c|c|c|c|}
\hline \multicolumn{9}{|c|}{ Y E A R } \\
\hline Study /Science & 2005 & 2006 & 2007 & 2008 & 2009 & 2010 & 2011 & 2012 \\
\hline natural & 240 & 237 & 228 & 191 & 435 & 461 & 431 & 451 \\
\hline technical & 11131 & 8503 & 7482 & 6899 & 12521 & 12369 & 11811 & 11720 \\
\hline agricultural & 2217 & 1617 & 1374 & 1174 & 1701 & 1466 & 1358 & 1348 \\
\hline $\begin{array}{c}\text { medical and } \\
\text { pharmacist }\end{array}$ & 529 & 412 & 457 & 568 & 819 & 827 & 865 & 838 \\
\hline community & 11713 & 10222 & 9122 & 10030 & 17051 & 19095 & 18506 & 18528 \\
\hline arts and culture & 462 & 412 & 422 & 474 & 751 & 879 & 849 & 852 \\
\hline $\begin{array}{c}\text { military and } \\
\text { security }\end{array}$ & 32 & 45 & 48 & 68 & 92 & 149 & 205 & 210 \\
\hline together & 26324 & 21448 & 19134 & 19404 & 33370 & 35246 & 34025 & 33947 \\
\hline
\end{tabular}

Sources of data: Basic statistical indicators of the labor market; monthly statistics ÚPSVR, own calculations; http: // www.upsvar.sk

The number of unemployed graduates is increasing mostly in the field of social sciences and services. Conversely, graduates of technical directions are increasingly in demand for labor and the number registered as unemployed is decreasing. Higher unemployment of graduates of educational and social sciences is to be considered more serious

\subsection{Graduate's unemployment according to the length of their registration as unemployed}

The following table shows the number of graduates by length of tally. As can be seen, the unemployment of graduates tends to shift higher to long-term unemployment, which is double in comparison to that of 2008. In the records of the unemployed there are more high school graduates. University graduates are in the labor office records for a shorter period of time before they can find a job, it is also due to higher qualifications.

Table 3. School enrollment by time records.

\begin{tabular}{|c|c|c|c|c|c|c|c|c|c|c|}
\hline & \multicolumn{10}{|c|}{ YEAR } \\
\hline month & $9 / 2008$ & $\%$ & $9 / 2009$ & $\%$ & $9 / 2010$ & $\%$ & $9 / 2011$ & $\%$ & $9 / 2012$ & $\%$ \\
\hline up to 3 & 14427 & $74,3 \%$ & 21658 & $64,9 \%$ & 21331 & $60,7 \%$ & 19459 & $57,3 \%$ & 18760 & $0,5 \%$ \\
\hline over 3-6 & 2792 & $14,4 \%$ & 5650 & $16,9 \%$ & 6130 & $17,5 \%$ & 6561 & $19,4 \%$ & 4350 & $14,0 \%$ \\
\hline over 6-9 & 545 & $2,8 \%$ & 1765 & $5,3 \%$ & 1327 & $3,8 \%$ & 1531 & $4,6 \%$ & 1490 & $4,9 \%$ \\
\hline over 9 -12 & 340 & $1,8 \%$ & 1173 & $3,5 \%$ & 968 & $2,7 \%$ & 948 & $2,8 \%$ & 925 & $2,98 \%$ \\
\hline $\begin{array}{c}\text { above } \\
12-15\end{array}$ & 1222 & $6,3 \%$ & 2963 & $8,9 \%$ & 5291 & $15,0 \%$ & 5208 & $15,3 \%$ & 5120 & $16,6 \%$ \\
\hline over 15-18 & 75 & $0,4 \%$ & 156 & $0,5 \%$ & 189 & $0,5 \%$ & 291 & $0,6 \%$ & 350 & $1,1 \%$ \\
\hline $\begin{array}{c}\text { of the } \\
\text { long-term }\end{array}$ & 1297 & $6,6 \%$ & 3119 & $9,3 \%$ & 5480 & $15,6 \%$ & 5499 & $16,2 \%$ & 5470 & $17,6 \%$ \\
\hline
\end{tabular}

Source: Basic statistical indicators of the labor market; monthly statistics ÚPSVR; own calculations; http: // www.upsvar.sk

Recommendations for practice: 
This analysis of unemployment of secondary schools and universities graduates showed structural disparities that exist in the labor market. Based on the findings of the analysis following may be recommended:

- close interrelationship of individual schools with employers and training carried out in those fields of study that are necessary for the labor market

- $\quad$ encourage schools and students to study specializations requested by the labor market

- better preparedness of young people in terms of language and communication, as well as management skills and their ability to support independent business activities

- establish a system of cooperation between schools and employers so that graduates gain working skills during their studies and are more prepared for the needs of practice

- the creation of system of employment policies should focus increasingly on employers who provide scope for reducing unemployment. It is also necessary to set up active policy instruments that will stimulate production of new job positions and which will also motivate the workforce to employ and eliminate those attempts which are decreasing effect and act as unsystematic.

\section{CONCLUSION}

In Slovakia, school graduates` unemployment has become a serious economic problem, which must be paid due attention by the State. Governments show efforts to create new job positions, they also generate different instruments of active labor market policies, but these tend to be unaddressed in many cases and rather abused by employers. As a result, graduates do not obtain job skills that employers require. Only coordination of all actors in the labor market may lead to systemic and comprehensive solution to the problem of unemployment of graduates.

Very positive element in the employment of the young generation is the motivation of employers, which can not be based on inefficient contributions, but must be based on a system of reciprocal benefits. Therefore various areas of state policy should be framed so that the state enters the economy with measures that will not restrict the rights and interests of business, but rather to encourage them to create new job positions. This issue, however, requires realistic analyses which have been insufficient or completely absent in Slovakia.

\section{References}

[1] NR SR Act No. 5/2004 Z.z. on employment services and amending certain acts as amended.

[2] Hanzelová, E. - Bellan, P. term unemployment in the EU with an emphasis on specifications, and the application of good practice in the Slovak Republic. Bratislava ECS no. 2139: Institute for Labour and Family (IVPR), 2009. Available at: http://www.sspr.gov.sk/texty/File/vyskum/2009/Hanzelova/ Hanzelova-Bellan.pdf

[3] Kešelová, D, causes of backwardness SR towards the Lisbon objectives in the area of employment - depth analysis of the level of employment and labor market position of specific groups. Bratislava - ECS no. 2140: Institute for Labour and Family (IVPR), 2009. Available at: 
[4] http://www.sspr.gov.sk/IVPR/images/IVPR/vyskum/2009/Keselova/Priciny_Keselova.pdf

[5] Matoušek, Ulrich et al. 2005. The social work practice. 1st edition. Prague: Portal, 2005th ISBN 80-7367-002-X.

[6] http://portal.statistics.sk/showdoc.do?docid=1933

[7] Zvalová et al. 2007. Application of graduates in practice: (IIPE report). Bratislava: IIPE, 2007.

[8] http://www.upsvar.sk/statistiky/nezamestnanost-absolventi-tatistiky/2003.html? page_id= 1328 